\title{
The neuroprotective steroid progesterone promotes mitochondrial uncoupling, reduces cytosolic calcium and augments stress resistance in yeast cells
}

\author{
Slaven Stekovic ${ }^{1, *}$, Christoph Ruckenstuhl ${ }^{1,+, *}$, Philipp Royer ${ }^{1}$, Christof Winkler-Hermaden ${ }^{1}$, Didac \\ Carmona-Gutierrez ${ }^{1}$, Kai-Uwe Fröhlich ${ }^{1}$, Guido Kroemer $^{3-8}$, and Frank Madeo ${ }^{1,2,+}$ \\ ${ }^{1}$ Institute of Molecular Biosciences, NAWI Graz, University of Graz, 8010 Graz, Austria. \\ ${ }^{2}$ BioTechMed Graz, Austria. \\ ${ }^{3}$ Equipe 11 labellisée par la Ligue contre le Cancer, Centre de Recherche des Cordeliers, Paris, France. \\ ${ }^{4}$ INSERM, U1138, Paris, France. \\ ${ }^{5}$ Université Paris Descartes, Sorbonne Paris Cité, Paris, France. \\ ${ }^{6}$ Cell Biology \& Metabolomics Platforms, Gustave Roussy Comprehensive Cancer Center, Villejuif, France. \\ ${ }^{7}$ Pôle de Biologie, Hôpital Européen Georges Pompidou, AP - HP, Paris, France. \\ ${ }^{8}$ Karolinska Institute, Department of Women's and Children's Health, Karolinska University Hospital, 17176 Stockholm, Sweden, \\ * These authors contributed equally. \\ ${ }^{+}$Corresponding Author: \\ Frank Madeo, Institute of Molecular Biosciences, University of Graz, Humboldtstrasse 50; 8010 Graz, Austria; E-mail:
}

frank.madeo@uni-graz.at

Christoph Ruckenstuhl, Institute of Molecular Biosciences, University of Graz, Humboldtstrasse 50; 8010 Graz, Austria; E-mail: ru.ruckenstuhl@uni-graz.at

\begin{abstract}
The steroid hormone progesterone is not only a crucial sex hormone, but also serves as a neurosteroid, thus playing an important role in brain function. Epidemiological data suggest that progesterone improves the recovery of patients after traumatic brain injury. Brain injuries are often connected to elevated calcium spikes, reactive oxygen species (ROS) and programmed cell death affecting neurons. Here, we establish a yeast model to study progesterone-mediated cytoprotection. External supply of progesterone protected yeast cells from apoptosis-inducing stress stimuli and resulted in elevated mitochondrial oxygen uptake accompanied by a drop in ROS generation and ATP levels during chronological aging. In addition, cellular $\mathrm{Ca}^{2+}$ concentrations were reduced upon progesterone treatment, and this effect occurred independently of known $\mathrm{Ca}^{2+}$ transporters and mitochondrial respiration. All effects were also independent of Dap1, the yeast orthologue of the progesterone receptor. Altogether, our observations provide new insights into the cytoprotective effects of progesterone.
\end{abstract}

doi: $10.15698 /$ mic2017.06.577 Received originally: 10.03.2017; In revised form: 21.05.2017, Accepted 22.05.2017, Published 31.05.2017.

\section{Keywords: TBl; traumatic brain} injury, cell protection, cell stress, cell death, neuroprotection, progesterone, mitochondrial uncoupling.
Abbreviations:
$D H E$ - dihydroethidium, $P C D$ - programmed cell death, ROS - reactive oxygen species, $T B I$ - traumatic brain injury.

\section{INTRODUCTION}

Progesterone is a sterol-derived hormone that is crucial for female reproductive capacity and plays major regulatory roles in the monthly menstrual cycle and upon conception as well as during pregnancy and embryogenesis. In addition, it also serves as a neurosteroid, thus playing an important role in brain function in both sexes [1]. For instance, progesterone inhibits the neuronal nicotinic acetylcholine receptor and stimulates the synthesis of myelin proteins [1]. Of note, progesterone has been linked to the gender-specific risk and outcome of brain injuries that is more favorable for females [2]. Interestingly, preclinical data strongly suggest that (high doses of) progesterone may positively affect recovery from traumatic brain injury (TBI) in model organisms [3-7], if administered before or shortly after TBI. Two clinical studies could confirm a neuroprotective effect of progesterone when administered shortly after TBI [8,9], while some more recent clinical data seem to disprove this hypothesis [10-12]. Therefore, it remains an open question 
A

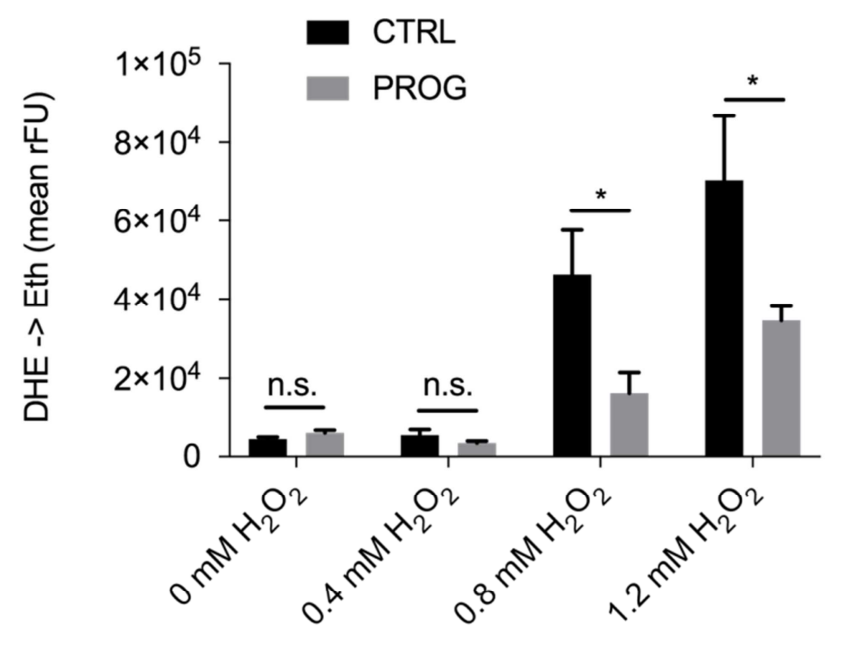

B

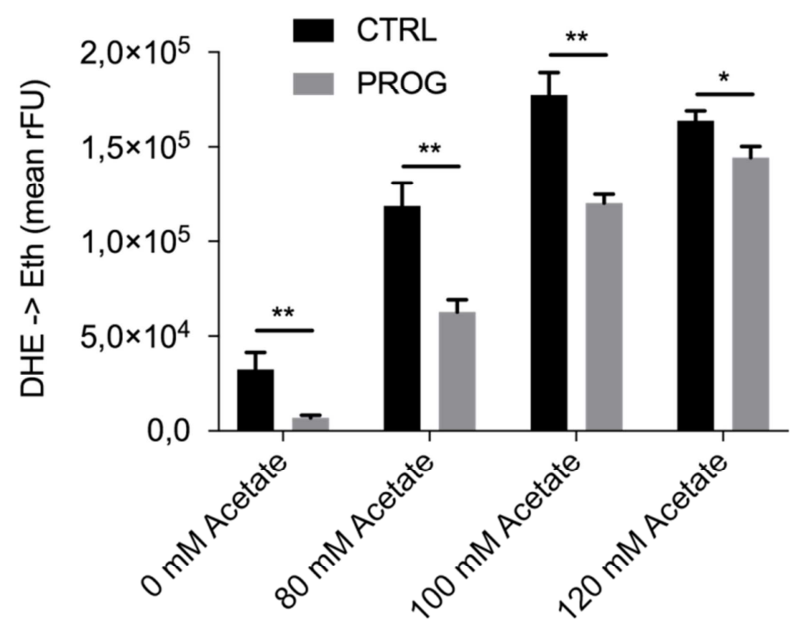

FIGURE 1: Progesterone treatment increases resistance of wildtype yeast to external stressors. ROS accumulation in yeast cells treated with progesterone $(10 \mu \mathrm{g} / \mathrm{ml})$ or left untreated as shown by the DHE to ethidium turnover rate upon hydrogen peroxide (A) or acetate (B) challenge during logarithmic phase. All data represent mean values ( $n=3 \pm S E M)$. Statistical analysis was conducted using non-paired Student's t-test. ${ }^{*}=p<0.05 ;{ }^{* *}=p<0.01 ; * * *=p<0.001 ;$ n.s. = non-significant, Prog = progesterone, ctrl = control.

if progesterone affects the recovery and survival after TBI in humans and to which extent it promotes cellular restauration.

In order to investigate the cytoprotective potential of progesterone, we took advantage of Saccharomyces cerevisiae, knowing that this organism has repeatedly been shown to be suitable for mechanistic studies of programmed cell death (PCD) [13-19]. Yeast is especially useful as a model to study neuroprotection at the cellular level [20-27]. Here, we describe the positive impact of progesterone on several parameters of cellular physiology. Importantly, our results also suggest a possible receptorindependent mechanism for these effects, since deletion of $D A P 1$ - a heme-binding protein related to the mammalian membrane progesterone receptor - did not alter susceptibility towards progesterone treatment. Altogether, we reveal that progesterone exerts potent cytoprotective effects in yeast.

\section{RESULTS}

\section{Progesterone increases stress tolerance}

Traumatic brain injury is connected to elevated PCD and ROS accumulation in the brain tissue $[28,29]$. Therefore, we tested if progesterone would render yeast cells less susceptible towards different stressors that are connected to an increase in ROS production. Upon addition of progesterone, wild type yeast cultures treated with $\mathrm{H}_{2} \mathrm{O}_{2}$ or acetate, which are both well-known PCD inducers in yeast [14,30-34], showed reduced ROS accumulation as measured by the ROS-driven conversion of dihydroethidium (DHE) to fluorescent ethidium (Figure 1A and B). Furthermore, under physiological culture conditions, in the absence of PCD inducers, progesterone significantly reduced ROS levels as compared to the untreated control (Figure 2A). Altogether, progesterone dampens ROS production in yeast, both in normal culture conditions and in the presence of external stress factors.

Progesterone impacts mitochondria by acting as a mild respiration-uncoupler

To further explore the mechanisms underlying progesterone cytoprotection, we next examined the physiology of mitochondria, since these organelles constitute one of the main sources of ROS [35-38]. Interestingly, while $\mathrm{O}_{2}$ consumption was significantly enhanced during progesterone treatment, ATP levels were reduced (Figure $2 \mathrm{~B}$ and $\mathrm{C}$ ). Altogether, this indicates an uncoupling phenotype with diminished oxidative phosphorylation. Accordingly, we observed reduced growth of wild type yeast upon progesterone treatment on a non-fermentable carbon source (glycerol), while no changes were detected on a fermentable carbon source (glucose) (Figure 2D and E). Importantly, this effect was also observed in a mutant strain lacking the heme-binding protein Dap1, which is the sole yeast orthologue of the human progesterone receptor (Figure 2D and E) [39]. Furthermore, we could demonstrate that stress protection by progesterone is respiration-dependent, since progesterone treatment did not confer stress resistance in respiration-deficient rho ${ }^{0}$ cells (Figure $2 \mathrm{~F}$ ). Altogether, it appears that progesterone impacts yeast mitochondrial respiration in a receptor-independent fashion.

Progesterone administration diminishes cytosolic $\mathrm{Ca}^{2+}$ concentrations both under physiological as well as under high calcium conditions

Next we investigated progesterone effects on $\mathrm{Ca}^{2+}$ homeostasis, knowing that mitochondria are one of the 
A

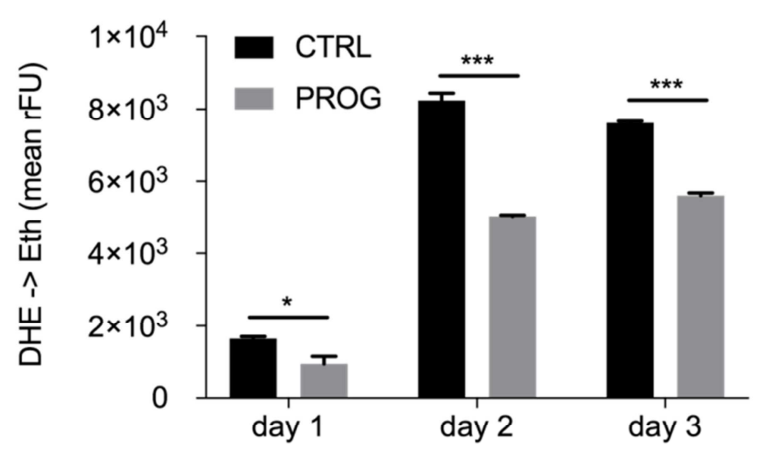

C

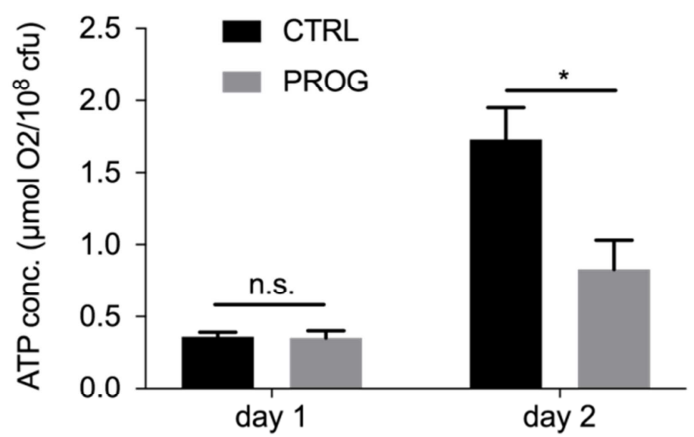

E

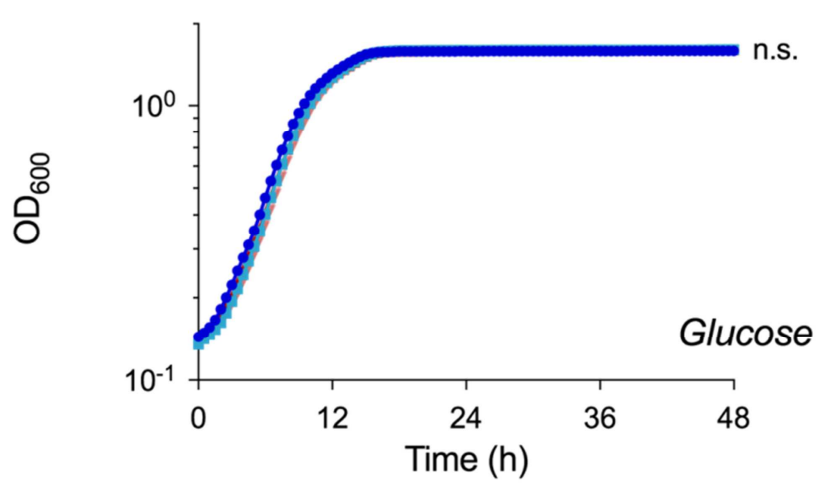

$\rightarrow$ CTRL, wildtype $\rightarrow$ CTRL, $\Delta$ dap1
$\rightarrow$ PROG, wildtype $\rightarrow$ PROG, $\Delta$ dap1
B

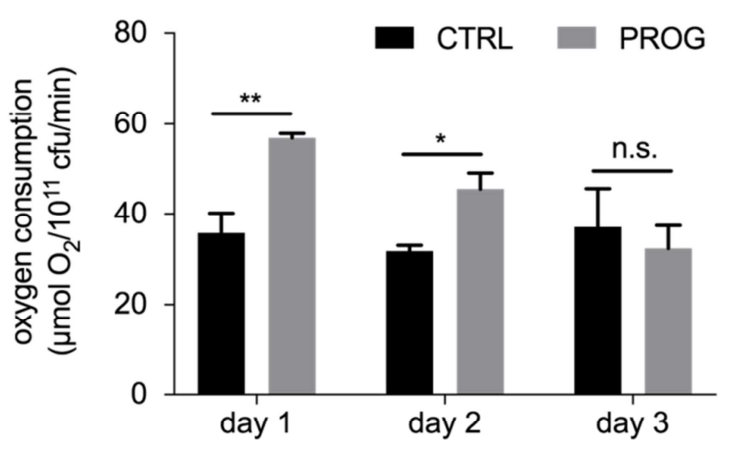

D

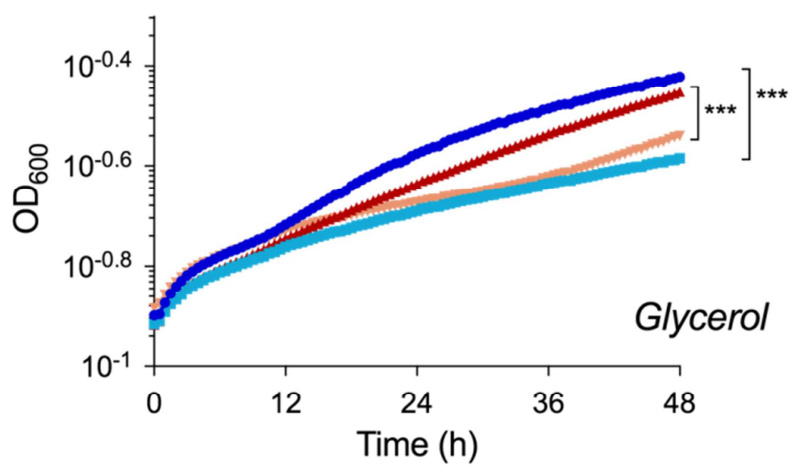

$F$
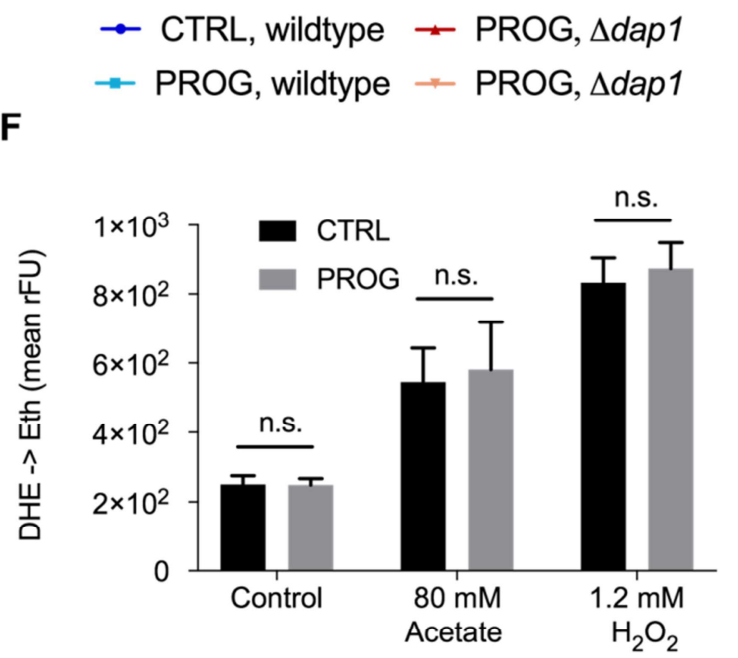

FIGURE 2: Progesterone impacts energy metabolism and reduces oxygen stress accumulation in wildtype yeast. Wildtype yeast were treated with $10 \mu \mathrm{g} / \mathrm{ml}$ progesterone and assayed for (A) ROS accumulation via DHE to ethidium turnover, (B) oxygen consumption via respirometry, and (C) ATP production. Growth curves of wildtype as well as $\Delta$ dap1 strains, with or without progesterone treatment, on glycerol (respiratory carbon source) (D) and glucose (fermentative carbon source) media (E). ROS accumulation in rho ${ }^{0}$ yeast cells $+/-$ progesterone (10 $\mu$ g/ml) treated or untreated with $\mathrm{H}_{2} \mathrm{O}_{2}$ or acetate during logarithmic phase $(F)$. All data represent mean values $(n=3-5 \pm \mathrm{SEM}$ ). Statistical analysis was conducted using non-paired Student t-test (A-C, F) or using a two-way repeated measurement ANOVA and multiple comparison post-hoc Tukey's test $(D, E) .{ }^{*}=p<0.05 ;{ }^{* *}=p<0.01 ; * * *=p<0.001 ;$ n.s. $=$ non-significant. ROS $=$ reactive oxygen species, $r F U=$ relative fluorescence units, Prog = progesterone, $\mathrm{ctrl}=$ control.

organelles 
responsible for buffering cytosolic $\mathrm{Ca}^{2+}$ under normal conditions [40]. Importantly, TBI, stroke, and even some forms of dementia cause $\mathrm{Ca}^{2+}$ accumulation in the cytosol of neurons followed by cell death and neurodegeneration [41]. Thus, we examined the capacity of yeast cells to process $\mathrm{Ca}^{2+}$ uptake under the influence of progesterone. Specifically, wild type yeast cell cultures were challenged with $150 \mathrm{mM} \mathrm{CaCl}_{2}$ and transient concentrations of cytoplasmic $\mathrm{Ca}^{2+}$ levels ([Ca $\left.\left.{ }^{2+}\right] \mathrm{cyt}\right)$ / responses were monitored. Progesterone caused a significantly reduced $\mathrm{Ca}^{2+}$ uptake capacity alongside with a faster reduction of cytoplasmic $\mathrm{Ca}^{2+}$ levels (Figure $3 \mathrm{~A}$ and $\mathrm{B}$ ). Of note, basal $\mathrm{Ca}^{2+}$ levels before and after the $\mathrm{Ca}^{2+}$ pulse were already lowered when cells were treated with progesterone (Figure 3B). However, mitochondrial respiration was not involved in this phenotype, since progesterone treatment continued to affect basic cytosolic $\mathrm{Ca}^{2+}$ levels in respiration-deficient rho ${ }^{0}$ cells (Figure $3 C$ and $D$ ).

To further investigate the observed phenotypes, we tested single-gene deletion mutants of all currently known $\mathrm{Ca}^{2+}$ channels/transporters in yeast, including the cytoplasmic membrane transporters Cch1 and Mid 1, the organelle transporters Vcx1, Pmr1, Cod1, Yvc1, and Pmc1 as well as Emc7, an ER protein associated to $\mathrm{Ca}^{2+}$ homeostasis. Although $\mathrm{Ca}^{2+}$ uptake and clearance was influenced by some of these gene deletion, all mutants continued to exhibit significantly reduced $\mathrm{Ca}^{2+}$ uptake when treated with progesterone (compare Supplemental Figure $1 A-G$ to $H$ ). Thus, the effects observed in wild type cells could not be reversed by single gene deletions in any of these transporters. Similarly, the effects of progesterone treatment on $\mathrm{Ca}^{2+}$ homeostasis/uptake were independent of the mammalian membrane progesterone receptor homolog Dap1 (Figure 3E and F). Taken together, progesterone seems to influence $\mathrm{Ca}^{2+}$ homeostasis/uptake in a general manner, independently from known $\mathrm{Ca}^{2+}$ transporters and respiration capacity.

\section{DISCUSSION}

Here, we establish $S$. cerevisiae as a model to investigate cytoprotection by progesterone. We observed that progesterone increased stress tolerance of yeast to the well-known PCD inducers $\mathrm{H}_{2} \mathrm{O}_{2}$ and acetate [14,30-34] as well as under physiological (control) conditions. Interestingly, progesterone treatment led to a mild uncoupling phenotype with higher $\mathrm{O}_{2}$ consumption (+50\%) but lower ATP levels (-50\%), arguing for a mitochondrial uncoupling effect. Indeed, growth on the non-fermentable carbon source glycerol was diminished in the presence of progesterone. Notably, mild uncoupling induced by chemical substances (such as dinitrophenol), caloric restriction or ectopic expression of mammalian uncoupling proteins in yeast - $S$. cerevisiae does not possess any known uncoupling proteins [42] - is known to increase lifespan [43-45]. Similarly, in mammalian aging cells, changes in mitochondrial energy metabolism caused by mitochondrial uncoupling seem to improve cellular fitness [46]. Progesterone treatment of human cells has been demonstrated to strongly increase the levels of mRNAs coding for uncoupling proteins [47]. Increased $\mathrm{O}_{2}$ consumption with decreased ${ }^{32} \mathrm{P}$ uptake (as a parameter for ATP production) has been reported for isolated rat mitochondria treated with progesterone [48]. Collectively, our data combined with those reported in the literature highlight the possibility to investigate progesteronemediated effects in the yeast model. The uncoupling aspect of progesterone, in fact, could represent one of the mechanisms of neuroprotection conferred by this steroid. In fact, the stress tolerance of a respiration-deficient rho strain was not influenced by progesterone treatment.

Progesterone had major effects on $\mathrm{Ca}^{2+}$ homeostasis and, in particular, on $\mathrm{Ca}^{2+}$ susceptibility/uptake. However, we could not identify any single $\mathrm{Ca}^{2+}$ channel in yeast that would influence these effects. However, we cannot exclude that yet unidentified $\mathrm{Ca}^{2+}$ channels or a combinations of known $\mathrm{Ca}^{2+}$ channels mediate these effects [49]. Another possible mode of action of progesterone on $\mathrm{Ca}^{2+}$ homeostasis could reside in its direct interaction with biological membranes. Since the chemical structure of progesterone shows four-ring as well as hydrophobic backbone and polar groups at both ends of the molecule, it could directly interact with cellular and mitochondrial membranes [50] and possibly influence their permeability towards inorganic cations (e.g. $\mathrm{Ca}^{2+}, \mathrm{H}^{+}$). This mode of action could connect our observations of mitochondrial uncoupling and modulation of $\mathrm{Ca}^{2+}$ homeostasis. Of note, a progesterone-treated rho ${ }^{0}$ strain still showed $\mathrm{Ca}^{2+}$ effects but no enhanced stress tolerance, suggesting that altered $\mathrm{Ca}^{2+}$ homeostasis may lie upstream of mitochondrial uncoupling. However, these mechanistic hypotheses remain to be empirically tested.

Certainly, the putative relevance of the herein described progesterone effects for TBI pathology remains to be explored. In some mammalian cell types, progesterone leads to a significant increase of intracellular $\mathrm{Ca}^{2+}[51,52]$, partly by activating protein kinase $\mathrm{C}[53]$ and depleting endocannabinoids by activating $\alpha / \beta$ hydrolase domain-containing protein 2 (ABHD2) [54]. However, in other cell types, progesterone withdrawal leads to an increased level of cytosolic $\mathrm{Ca}^{2+}$ [55]. While progesterone was not able to reduce estrogen-induced $\mathrm{Ca}^{2+}$ uptake in the rabbit myometrial smooth muscle cells, it increased the accumulation of $\mathrm{Ca}^{2+}$ in mitochondria [55]. This suggests that progesterone withdrawal reduces both myometrial cytosolic $\mathrm{Ca}^{2+}$ levels as well as the capacity of these cells to accumulate $\mathrm{Ca}^{2+}$ in different cellular compartments. Similar effects were reported for other types of smooth muscles $[56,57]$ and are believed to be caused by regulation of the inward current through L-type $\mathrm{Ca}^{2+}$ channels $[56,58]$. In neurons, the influence on $\mathrm{Ca}^{2+}$ signaling and the following inhibition of excitotoxic neuron death seem to be the neuroprotective mechanism induced by acute administration of progesterone after various neuronal injuries [59-61]. Indeed, progesterone might mediate broad neuroprotective effects, not only in the context of TBI but also in other pathologies $[62,63]$.

The role of progesterone in the pathological develop- 
A

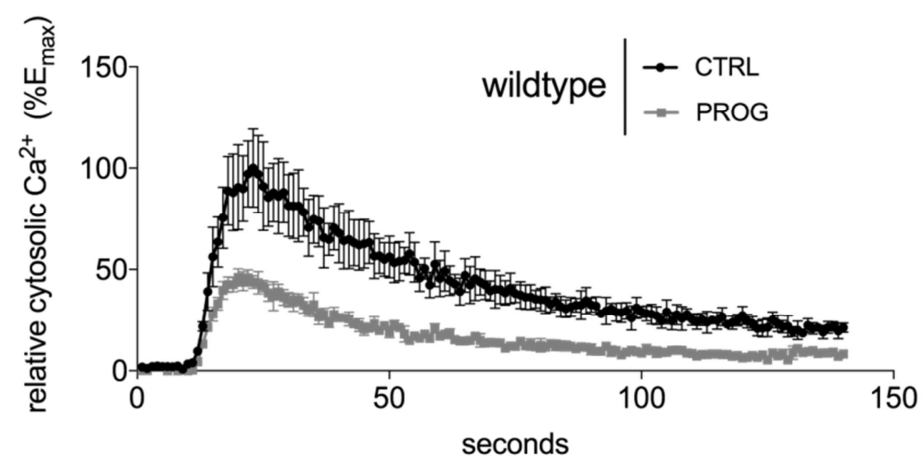

C

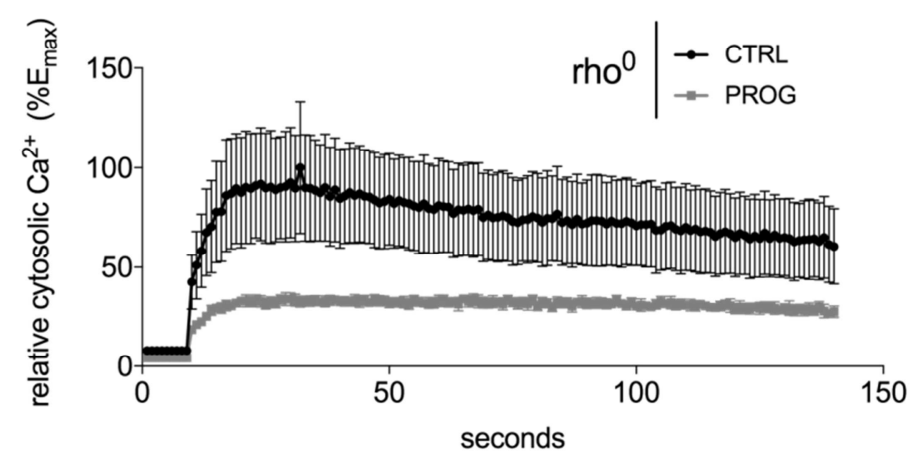

E

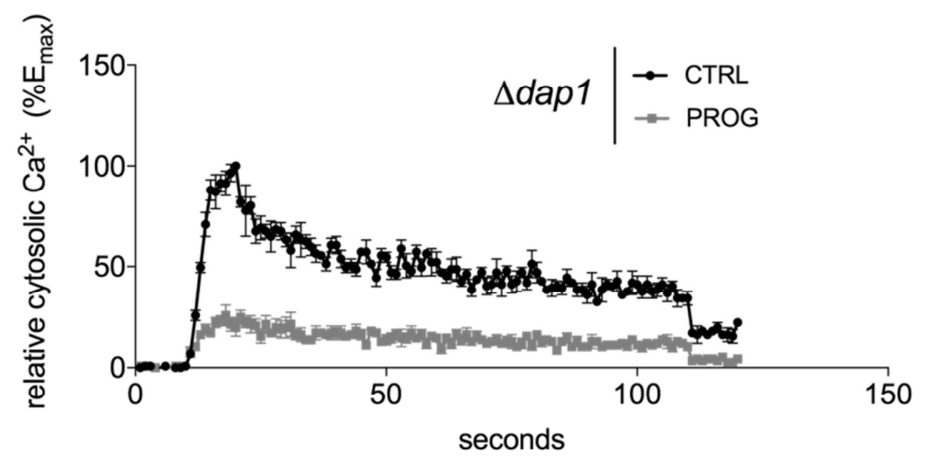

B

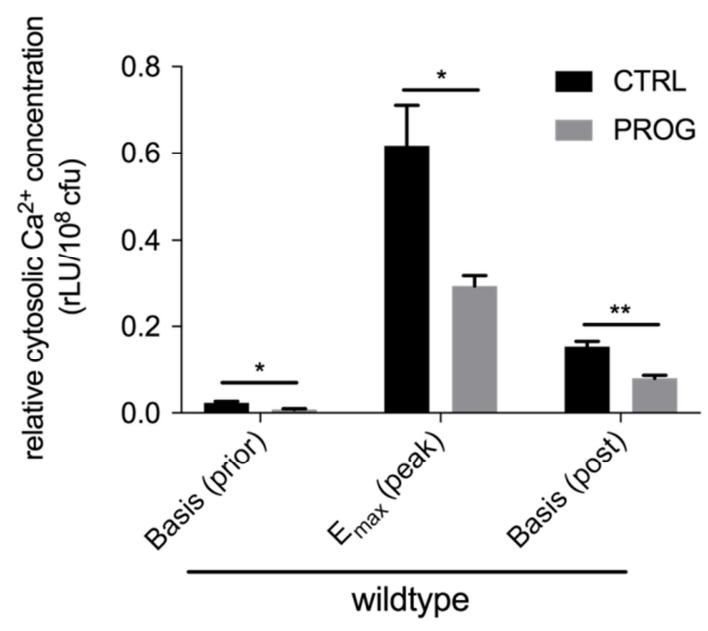

D

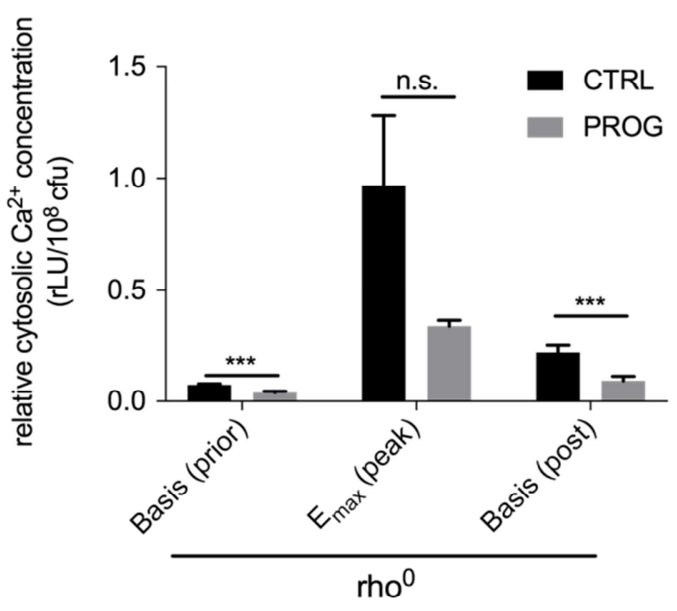

$\mathbf{F}$

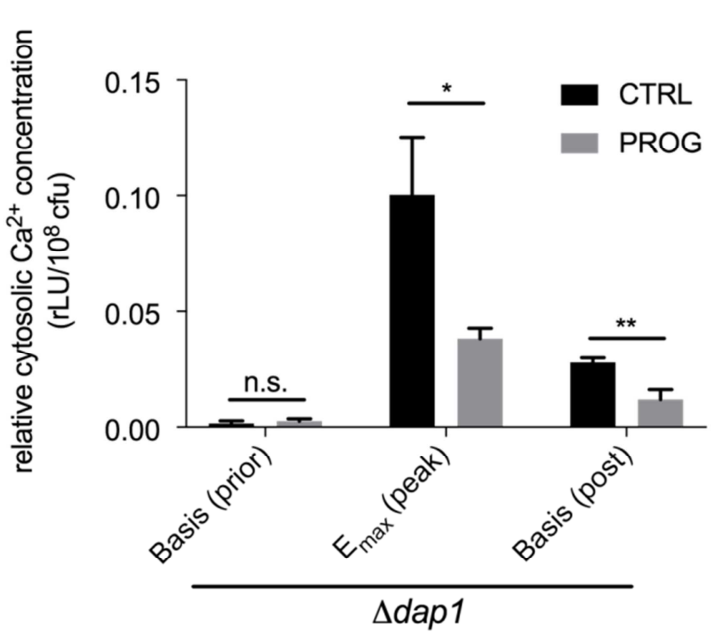

FIGURE 3: Cellular $\mathrm{Ca}^{2+}$ homeostasis is modulated by progesterone treatment in yeast. Cells were treated with progesterone $(10 \mu \mathrm{g} / \mathrm{ml})$ and challenged with high doses of $\mathrm{Ca}^{2+}(150 \mathrm{mM})$. Intake of $\mathrm{Ca}^{2+}$ as well as $\mathrm{Ca}^{2+}$-clearance in the cytosol to its basal level were measured in wild type $(\mathbf{A}, \mathbf{B})$, a DAP1-deletion strain (C,D), as well as in a rho strain, incapable of mitochondrial respiration (E,F). Data are shown as mean values of at least three replicates including the standard error of the mean. Statistical analysis was conducted using non-paired Student's $t$-test. ${ }^{*}=p<0.05$; $*^{* *}=p<0.01 ; * * *=p<0.001 ; n . s .=$ non-significant. $E_{\max }=$ global maximum of the respective ethanol-treated control; rLU = relative luminiscence units, $\operatorname{Prog}=$ progesterone, $\mathrm{ctrl}=$ control . 
ment of TBI has been well described in recent years. It has been shown that progesterone improves the function of the blood-brain-barrier after TBI [64]. Progesterone also increases the level of circulating endothelial cells, which in turn improves neovascularization and vascular remodeling in the brain [65]. Furthermore, progesterone treatment reduces neuroinflammation and oxidative stress [66] as it improves remyelination and functional recovery [63].

Interestingly, the intracellular effects exerted by progesterone in our model - reduced intracellular $\mathrm{Ca}^{2+}$ levels, uncoupled mitochondria and ROS reduction - were not lost when the sole possible yeast orthologue of the human progesterone receptor was removed from the system. This suggests that progesterone mediates its broad cytoprotective effects through other proteins than steroid receptors or perhaps with cellular membrane lipids. We surmise that yeast constitutes an ideal platform for exploring these effects in further detail.

\section{MATERIALS AND METHODS}

\section{Growth conditions}

S. cerevisiae strains (Table 1 ) were inoculated to $5 * 10^{5}$ (for growth curve $\mathrm{OD}_{600}$ of 0.05 ) cells in $\mathrm{SC}$ medium containing $0.17 \%$ yeast nitrogen base (BD Diagnostics; without ammonium sulfate and amino acids), $0.5 \%\left(\mathrm{NH}_{4}\right)_{2} \mathrm{SO}_{4}, 30 \mathrm{mg} / \mathrm{L}$ of all amino acids (except $80 \mathrm{mg} / \mathrm{L}$ histidine and $200 \mathrm{mg} / \mathrm{L}$ leucine), $30 \mathrm{mg} / \mathrm{L}$ adenine, and $320 \mathrm{mg} / \mathrm{L}$ uracil with $2 \%$ glucose (SCD) or alternatively with $3 \%$ glycerol (SCGly), w/o treatment with progesterone $(10 \mu \mathrm{g} / \mathrm{ml}$; Sigma Aldrich, Catalogue Nr. P0130). Controls were treated with respective solvent $(\mathrm{EtOH})$. Where indicated, stress (acetate or $\mathrm{H}_{2} \mathrm{O}_{2}$ ) was inflicted as described previously in mid-log phase ( $6 \mathrm{~h}$ of growth, culture density 2 $4 * 10^{6}$ cells $/ \mathrm{ml}$ ). Due to the inherent reduced respiration-rate of BY4741 strains, TB50a strains were used for respirationrelated experiments. DAP1 deletion was carried out by classical homologous recombination $[67,68]$.

\section{Growth curve}

Cells from ONC in SCD media were inoculated to an $\mathrm{OD}_{600}$ of 0.05 in SCD media and SCGly media with or without $10 \mu \mathrm{g} / \mathrm{ml}$ progesterone addition. Untreated cultures were supplemented with $0.1 \% \mathrm{EtOH}$ for solvent control. To obtain growth curves, $300 \mu \mathrm{l}$ of respective cultures per well were transferred into Honeycomb ${ }^{\circledast}$ plates, and measured with Bioscreen C MBR system (Oy Growth Curves Ab Ltd.) for a period of 48 hours at $28^{\circ} \mathrm{C}$, using continuous shaking and $\mathrm{OD}_{600}$ measurements every 30 minutes.

\section{Oxygen consumption measurement \\ Oxygen consumption was measured using a FireSting oxygen electrode (Pyro-Science) under constant stirring at a tempera- ture of $28.0 \pm 0.2^{\circ} \mathrm{C}$ in sealed $2 \mathrm{ml}$ bottles. The corresponding cell counts were measured using a CASY Cell Counter, whereas percentage of living cells in the sample were established by flow cytometry with propidium iodide (PI: $100 \mathrm{ng} / \mathrm{ml}$ ) stained samples. The slope of the oxygen concentration as the func- tion of time in its linear region was calculated and normalized to the number of living cells in the sample.}

ROS accumulation (DHE) assay

Oxidation of non-fluorescent di-hydroethidium (DHE) to fluo-

Table 1. Strains used in this study.

\begin{tabular}{|c|c|c|}
\hline Strain & Genotype & Reference \\
\hline TB50a wildtype & MATa; leu2-3,112 ura3-52 trp1 his3 rme1 HMLa & [69] \\
\hline TB50a $\triangle$ dap1 & MATa; leu2-3,112 ura3-52 trp1 his3 rme1 HMLa dap1::kanMX & This study \\
\hline BY4741 wildtype & MATa his $3 \Delta 1$ leu2 $\Delta 0$ met $15 \Delta 0$ ura3 $\Delta 0$ & Euroscarf \\
\hline BY4741 $\Delta d a p 1$ & MATa his $3 \Delta 1$ leu $2 \Delta 0$ met $15 \Delta 0$ ura3 $\Delta 0$ dap1::kanMX & Euroscarf \\
\hline BY4741 $\Delta c c h 1$ & MATa his $3 \Delta 1$ leu2 $\Delta 0$ met $15 \Delta 0$ ura3 $\Delta 0$ cch1::kanMX & Euroscarf \\
\hline BY4741 $\Delta$ mid1 & MATa his3 31 leu2 $\Delta 0$ met $15 \Delta 0$ ura3 $\Delta 0$ mid1::kanMX & Euroscarf \\
\hline BY4741 $\Delta v c x 1$ & MATa his $3 \Delta 1$ leu $2 \Delta 0$ met $15 \Delta 0$ ura3 $\Delta 0$ vcx1::kanMX & Euroscarf \\
\hline BY4741 $\Delta p m r 1$ & MATa his3 $\Delta 1$ leu2 $\Delta 0$ met15 $\Delta 0$ ura3 $\Delta 0$ pmr1::kanMX & Euroscarf \\
\hline BY4741 $\Delta \operatorname{cod} 1$ & MATa his $3 \Delta 1$ leu $2 \Delta 0$ met $15 \Delta 0$ ura $3 \Delta 0$ cod1::kanMX & Euroscarf \\
\hline BY4741 $\Delta y v c 1$ & MATa his $3 \Delta 1$ leu2 $\Delta 0$ met $15 \Delta 0$ ura3 $\Delta 0$ yvc1::kanMX & Euroscarf \\
\hline BY4741 $\Delta p m c 1$ & MATa his3 $\Delta 1$ leu2 $\Delta 0$ met15 $\Delta 0$ ura3 $\Delta 0$ pmc1::kanMX & Euroscarf \\
\hline BY4741 $\Delta e m c 7$ & MATa his $3 \Delta 1$ leu2 $\Delta 0$ met $15 \Delta 0$ ura3 $\Delta 0$ emc7::kanMX & Euroscarf \\
\hline
\end{tabular}


rescent ethidium was used to measure ROS accumulation in yeast cells [38]. Approximately $5 * 10^{6}$ cells from each sample were collected, washed and incubated with DHE solution (2.5 $\mu \mathrm{g} / \mathrm{ml}$ in PBS) for $10 \mathrm{~min}$ in the dark. After washing samples were re-suspended in PBS buffer and measured using flow cytometry. The relative mean fluorescence measured for the cell population was used for analysis [70].

\section{Boiling ethanol extraction of ATP and ATP measurement}

ATP extraction was done with flash-frozen cells by adding 0.5 $\mathrm{ml}$ preheated $\left(90^{\circ} \mathrm{C}\right)$ BES buffer and incubation at $90^{\circ} \mathrm{C}$ for 3 minutes. After centrifugation, supernatants were stored at $80^{\circ} \mathrm{C}$ until the measurement. ATP levels were determined by using the ATP detection kit from Invitrogen in a Luminoskan (Thermo Scientific).

\section{Cytosolic $\mathrm{Ca}^{2+}$ measurements}

$\left[\mathrm{Ca}^{2+}\right] c y t$ were measured using yeast strains carrying the vector pYX212 encoding the bioluminescent protein aequorin under the control of a TPI promoter. For analysis of the cellular response to high doses of external $\mathrm{Ca}^{2+}$, an equivalent of $6 * 10^{6}$ cells was harvested, resuspended in $200 \mu$ I SCD containing $4 \mu \mathrm{M}$ coelenterazine and incubated for $1 \mathrm{~h}$ in the dark. After washing cells were measured in a Luminoskan for $10 \mathrm{~s}$ and then challenged with high dose of $\mathrm{Ca}^{2+}$ (pump injection of $150 \mathrm{mM} \mathrm{Ca}^{2+}$ ). Kinetics were recorded over $120 \mathrm{~s}$. The luminescence signal was normalized to the $\mathrm{OD}_{600}$ of each well and reported in relative luminescence units, normalized to the global maximum value of the ethanol treated control of the respective run for better comparability.

\section{ACKNOWLEDGEMENTS}

We thank Silvia Dichtinger for technical assistance. FM is grateful to the Austrian Science Fund FWF (Austria) for grants P23490-B20, P29262, P24381, P29203 P27893, I1000 and 'SFB Lipotox' (F3012), as well as to BMWFW and the Karl-Franzens University for grant 'Unkonventionelle Forschung' and grant DKplus Metabolic and Cardiovascular Diseases (W1226). We acknowledge support from NAWI Graz and the BioTechMed-Graz flagship project "EPIAge". GK is supported by the Ligue contre le Cancer Comité de

\section{REFERENCES}

1. Baulieu E and Schumacher M (2000). Progesterone as a neuroactive neurosteroid, with special reference to the effect of progesterone on myelination. Steroids 65(10-11): 605-612.

2. Vagnerova K, Koerner IP, and Hurn PD (2008). Gender and the Injured Brain. Anesth Analg 107(1): 201-214.

3. Meffre D, Labombarda F, Delespierre B, Chastre A, De Nicola AF, Stein DG, Schumacher $M$, and Guennoun $R$ (2013). Distribution of membrane progesterone receptor alpha in the male mouse and rat brain and its regulation after traumatic brain injury. Neuroscience 231: 111-124.

4. Si D, Wang H, Wang Q, Zhang C, Sun J, Wang Z, Zhang Z, and Zhang $Y$ (2013). Progesterone treatment improves cognitive outcome following experimental traumatic brain injury in rats. Neurosci Lett 553: 1823.

5. Soltani Z, Khaksari M, Shahrokhi N, Mohammadi G, Mofid B, Vaziri A, and Amiresmaili $S$ (2016). Effect of estrogen and/or progesterone administration on traumatic brain injury-caused brain edema: the
Charente-Maritime (équipe labelisée); Agence National de la Recherche (ANR) - Projets blancs; ANR under the frame of E-Rare-2, the ERA-Net for Research on Rare Diseases; Association pour la recherche sur le cancer (ARC); Cancéropôle Ile-de-France; Institut National du Cancer (INCa); Inserm (HTE); Institut Universitaire de France; Fondation pour la Recherche Médicale (FRM); the European Commission (ArtForce); the European Research Council (ERC); Fondation Carrefour; the LeDucq Foundation; the LabEx Immuno-Oncology; the RHU Torino Lumière, the SIRIC Stratified Oncology Cell DNA Repair and Tumor Immune Elimination (SOCRATE); the SIRIC Cancer Research and Personalized Medicine (CARPEM); and the Paris Alliance of Cancer Research Institutes (PACRI).

\section{SUPPLEMENTAL MATERIAL}

All supplemental data for this article are available online at www.microbialcell.com.

\section{CONFLICT OF INTEREST}

The authors declare no conflict of interest.

\section{COPYRIGHT}

(C) 2017 Stekovic et al. This is an open-access article released under the terms of the Creative Commons Attribution (CC BY) license, which allows the unrestricted use, distribution, and reproduction in any medium, provided the original author and source are acknowledged.

Please cite this article as: Slaven Stekovic, Christoph Ruckenstuhl, Philipp Royer, Christof Winkler-Hermaden, Didac CarmonaGutierrez, Kai-Uwe Fröhlich, Guido Kroemer, and Frank Madeo (2017). The neuroprotective steroid progesterone promotes mitochondrial uncoupling, reduces cytosolic calcium and augments stress resistance in yeast cells. Microbial Cell 4(6): 191-199. doi: 10.15698/mic2017.06.577

changes of aquaporin-4 and interleukin-6. J Physiol Biochem 72(1): 33-44.

6. Carswell HV, Anderson NH, Clark JS, Graham D, Jeffs B, Dominiczak $A F$, and Macrae IM (1999). Genetic and gender influences on sensitivity to focal cerebral ischemia in the stroke-prone spontaneously hypertensive rat. Hypertens Dallas Tex 1979 33(2): 681-685.

7. Alkayed NJ, Murphy SJ, Traystman RJ, Hurn PD, and Miller VM (2000). Neuroprotective effects of female gonadal steroids in reproductively senescent female rats. Stroke 31(1): 161-168.

8. Xiao G, Wei J, Yan W, Wang W, and Lu Z (2008). Improved outcomes from the administration of progesterone for patients with acute severe traumatic brain injury: a randomized controlled trial. Crit Care Lond Engl 12(2): R61.

9. Wright DW, Kellermann AL, Hertzberg VS, Clark PL, Frankel M, Goldstein FC, Salomone JP, Dent LL, Harris OA, Ander DS, Lowery DW, Patel MM, Denson DD, Gordon AB, Wald MM, Gupta S, Hoffman SW, and 
Stein DG (2007). ProTECT: A Randomized Clinical Trial of Progesterone for Acute Traumatic Brain Injury. Ann Emerg Med 49(4): 391-402.e2.

10. Skolnick BE, Maas Al, Narayan RK, van der Hoop RG, MacAllister T, Ward JD, Nelson NR, Stocchetti N, and SYNAPSE Trial Investigators (2014). A clinical trial of progesterone for severe traumatic brain injury N Engl J Med 371(26): 2467-2476.

11. Lin C, He H, Li Z, Liu Y, Chao H, Ji J, and Liu N (2015). Efficacy of progesterone for moderate to severe traumatic brain injury: a metaanalysis of randomized clinical trials. Sci Rep 5: 13442.

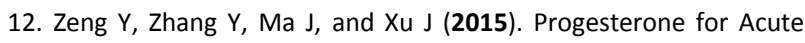
Traumatic Brain Injury: A Systematic Review of Randomized Controlled Trials. PloS One 10(10): e0140624.

13. Madeo F, Fröhlich E, and Fröhlich KU (1997). A yeast mutant showing diagnostic markers of early and late apoptosis. J Cell Biol 139(3): 729-734.

14. Madeo F, Fröhlich E, Ligr M, Grey M, Sigrist SJ, Wolf DH, and Fröhlich KU (1999). Oxygen stress: a regulator of apoptosis in yeast. J Cell Biol 145(4): 757-767.

15. Madeo F, Herker E, Maldener C, Wissing S, Lächelt S, Herlan M, Fehr M, Lauber K, Sigrist SJ, Wesselborg S, and Fröhlich KU (2002). A caspase-related protease regulates apoptosis in yeast. Mol Cell 9(4): 911-917.

16. Herker $E$, Jungwirth $H$, Lehmann KA, Maldener C, Fröhlich K-U, Wissing S, Büttner S, Fehr M, Sigrist S, and Madeo F (2004). Chronological aging leads to apoptosis in yeast. J Cell Biol 164(4): 501-507.

17. Wissing $S$, Ludovico $P$, Herker $E$, Büttner $S$, Engelhardt $S M$, Decker T, Link A, Proksch A, Rodrigues F, Corte-Real M, Fröhlich K-U, Manns J, Candé C, Sigrist SJ, Kroemer G, and Madeo F (2004). An AIF orthologue regulates apoptosis in yeast. J Cell Biol 166(7): 969-974.

18. Büttner S, Ruli D, Vögtle F-N, Galluzzi L, Moitzi B, Eisenberg T, Kepp $\mathrm{O}$, Habernig L, Carmona-Gutierrez D, Rockenfeller $\mathrm{P}$, Laun $\mathrm{P}$, Breitenbach $M$, Khoury C, Fröhlich K-U, Rechberger G, Meisinger C, Kroemer $\mathrm{G}$, and Madeo $\mathrm{F}$ (2011). A yeast BH3-only protein mediates the mitochondrial pathway of apoptosis. EMBO J 30(14): 2779-2792.

19. Galluzzi L, Kepp O, and Kroemer G (2016). Mitochondrial regulation of cell death: a phylogenetically conserved control. Microb Cell 3(3): 101-108.

20. Büttner S, Habernig L, Broeskamp F, Ruli D, Vögtle FN, Vlachos $M$, Macchi F, Küttner V, Carmona-Gutierrez D, Eisenberg T, Ring J, Markaki $M$, Taskin AA, Benke S, Ruckenstuhl $C$, Braun R, Van den Haute $C$, Bammens T, van der Perren A, Fröhlich K-U, Winderickx J, Kroemer G, Baekelandt V, Tavernarakis N, Kovacs GG, Dengjel J, Meisinger C, Sigrist SJ, and Madeo F (2013). Endonuclease $G$ mediates $\alpha$-synuclein cytotoxicity during Parkinson's disease. EMBO J 32(23): 3041-3054.

21. Büttner S, Broeskamp F, Sommer C, Markaki M, Habernig L, Alavian-Ghavanini A, Carmona-Gutierrez D, Eisenberg T, Michael E, Kroemer G, Tavernarakis N, Sigrist SJ, and Madeo F (2014). Spermidine protects against $\alpha$-synuclein neurotoxicity. Cell Cycle Georget Tex 13(24): 3903-3908.

22. Heinisch JJ and Brandt R (2016). Signaling pathways and posttranslational modifications of tau in Alzheimer's disease: the humanization of yeast cells. Microb Cell 3(4): 135-146.

23. Menezes R, Tenreiro S, Macedo D, Santos C, and Outeiro T (2015). From the baker to the bedside: yeast models of Parkinson's disease. Microb Cell 2(8): 262-279.

24. Amen $T$ and Kaganovich D (2016). Yeast screening platform identifies FDA-approved drugs that reduce $A \beta$ oligomerization. Microb Cell 3(3): 97-100.
25. Shrestha A and Megeney $L$ (2015). Yeast proteinopathy models: a robust tool for deciphering the basis of neurodegeneration. Microb Cell 2(12): 458-465.

26. Bond M, Brown R, Rallis C, Bahler J, and Mole S (2015). A central role for TOR signalling in a yeast model for juvenile CLN3 disease. Microb Cell 2(12): 466-480.

27. Carmona-Gutierrez D, Hughes AL, Madeo F, and Ruckenstuhl C (2016). The crucial impact of lysosomes in aging and longevity. Ageing Res Rev 32: 2-12. doi: 10.1016/j.arr.2016.04.009.

28. Raghupathi R (2004). Cell death mechanisms following traumatic brain injury. Brain Pathol Zurich Switz 14(2): 215-222.

29. Cheng G, Kong R, Zhang L, and Zhang J (2012). Mitochondria in traumatic brain injury and mitochondrial-targeted multipotential therapeutic strategies: Mitochondria in traumatic brain injury. $\mathbf{B r} \mathbf{J}$ Pharmacol 167(4): 699-719.

30. Ludovico P, Sousa MJ, Silva MT, Leão C, and Côrte-Real M (2001). Saccharomyces cerevisiae commits to a programmed cell death process in response to acetic acid. Microbiol Read Engl 147(Pt 9): 24092415

31. Rockenfeller P, Ring J, Muschett V, Beranek A, Buettner S, Carmona-Gutierrez D, Eisenberg T, Khoury $C$, Rechberger G, Kohlwein SD, Kroemer $G$, and Madeo F (2010). Fatty acids trigger mitochondriondependent necrosis. Cell Cycle Georget Tex 9(14): 2836-2842.

32. Eisenberg T, Carmona-Gutierrez D, Büttner S, Tavernarakis N, and Madeo F (2010). Necrosis in yeast. Apoptosis Int J Program Cell Death 15(3): 257-268.

33. Carmona-Gutiérrez $D$, Bauer MA, Ring J, Knauer $H$, Eisenberg $T$, Büttner S, Ruckenstuhl C, Reisenbichler A, Magnes C, Rechberger GN, Birner-Gruenberger R, Jungwirth H, Fröhlich K-U, Sinner F, Kroemer G, and Madeo $F$ (2011). The propeptide of yeast cathepsin D inhibits programmed necrosis. Cell Death Dis 2: e161.

34. Braun RJ, Sommer C, Carmona-Gutierrez D, Khoury CM, Ring J, Büttner $S$, and Madeo $F$ (2011). Neurotoxic 43-kDa TAR DNA-binding protein (TDP-43) triggers mitochondrion-dependent programmed cell death in yeast. J Biol Chem 286(22): 19958-19972.

35. Holmström KM and Finkel T (2014). Cellular mechanisms and physiological consequences of redox-dependent signalling. Nat Rev Mol Cell Biol 15(6): 411-421.

36. Braun RJ, Sommer C, Leibiger C, Gentier RJG, Dumit VI, Paduch K, Eisenberg T, Habernig L, Trausinger G, Magnes C, Pieber T, Sinner F, Dengjel J, van Leeuwen FW, Kroemer G, and Madeo F (2015). Accumulation of Basic Amino Acids at Mitochondria Dictates the Cytotoxicity of Aberrant Ubiquitin. Cell Rep 10(9): 1557-1571.

37. Braun R, Sommer C, Leibiger C, Gentier R, Dumit V, Paduch K, Eisenberg T, Habernig L, Trausinger G, Magnes C, Pieber T, Sinner F, Dengjel J, van Leeuwen F, Kroemer G, and Madeo F (2015). Modeling non-hereditary mechanisms of Alzheimer disease during apoptosis in yeast. Microb Cell 2(4): 136-138.

38. Ruckenstuhl C, Büttner S, Carmona-Gutierrez D, Eisenberg T, Kroemer G, Sigrist SJ, Fröhlich K-U, and Madeo F (2009). The Warburg Effect Suppresses Oxidative Stress Induced Apoptosis in a Yeast Model for Cancer. PLoS ONE 4(2): e4592.

39. Hand RA, Jia N, Bard M, and Craven RJ (2003). Saccharomyces cerevisiae Dap1p, a novel DNA damage response protein related to the mammalian membrane-associated progesterone receptor. Eukaryot Cell 2(2): 306-317.

40. Gregor A, Kocyłowski M, and Kostrzewska E (1986). Evaluation of the diagnostic usefulness of determining porphobilinogen deaminase activity in the erythrocytes in patients with acute intermittent porphy- 
ria and in carriers of the gene of this type of porphyria. Przegl Lek 43(11): 703-705.

41. Tubiana N, Mishal Z, le Caer F, Seigneurin JM, Berthoix Y, Martin $\mathrm{PM}$, and Carcassonne $Y$ (1986). Quantification of oestradiol binding at the surface of human lymphocytes by flow cytofluorimetry. Br J Cancer 54(3): 501-504.

42. Roussel D, Harding M, Runswick MJ, Walker JE, and Brand MD (2002). Does any yeast mitochondrial carrier have a native uncoupling protein function? J Bioenerg Biomembr 34(3): 165-176.

43. Barros MH, Bandy B, Tahara EB, and Kowaltowski AJ (2004). Higher respiratory activity decreases mitochondrial reactive oxygen release and increases life span in Saccharomyces cerevisiae. J Biol Chem 279(48): 49883-49888.

44. Skulachev VP (1998). Uncoupling: new approaches to an old problem of bioenergetics. Biochim Biophys Acta BBA - Bioenerg 1363(2): 100-124.

45. Mookerjee SA, Divakaruni AS, Jastroch M, and Brand MD (2010). Mitochondrial uncoupling and lifespan. Mech Ageing Dev 131(7-8): 463-472.

46. Amara CE, Shankland EG, Jubrias SA, Marcinek DJ, Kushmerick MJ, and Conley KE (2007). Mild mitochondrial uncoupling impacts cellular aging in human muscles in vivo. Proc Natl Acad Sci 104(3): 1057-1062.

47. Rodriguez AM, Monjo M, Roca P, and Palou A (2002). Opposite actions of testosterone and progesterone on UCP1 mRNA expression in cultured brown adipocytes. Cell Mol Life Sci CMLS 59(10): 17141723.

48. Wade Ruth and Jones Howard W. Jr. (1956). Effect of progesterone on mitochondrial adenosinetriphospatase. JBC 220: 547-551.

49. Liu W (2012). Control of Calcium in Yeast Cells. Introduction to Modeling Biological Cellular Control Systems. Springer Milan, Milano; pp. 95-122.

50. Ren ZW (1992). Radiofrequency ablation of left-sided atrioventricular accessory tract to treat supraventricular tachycardia. Zhonghua Xin Xue Guan Bing Za Zhi 20(4): 212-214.

51. Romarowski A, Sánchez-Cárdenas C, Ramírez-Gómez HV, Puga Molina L del C, Treviño CL, Hernández-Cruz A, Darszon A, and Buffone MG (2016). A Specific Transitory Increase in Intracellular Calcium Induced by Progesterone Promotes Acrosomal Exocytosis in Mouse Sperm. Biol Reprod 94(3): 63.

52. Li L-F, Xiang C, Zhu Y-B, and Qin K-R (2014). Modeling of progesterone-induced intracellular calcium signaling in human spermatozoa. J Theor Biol 351: 58-66.

53. Bonaccorsi L (1998). Progesterone-stimulated intracellular calcium increase in human spermatozoa is protein kinase $\mathrm{C}$-independent. Mol Hum Reprod 4(3): 259-268.

54. Miller MR, Mannowetz N, lavarone AT, Safavi R, Gracheva EO, Smith JF, Hill RZ, Bautista DM, Kirichok Y, and Lishko PV (2016). Unconventional endocannabinoid signaling governs sperm activation via the sex hormone progesterone. Science 352(6285): 555-559.

55. Batra S (1986). Effect of estrogen and progesterone treatment on calcium uptake by the myometrium and smooth muscle of the lower urinary tract. Eur J Pharmacol 127(1-2): 37-42.

56. Barbagallo M, Dominguez LJ, Licata G, Shan J, Bing L, Karpinski E, Pang PKT, and Resnick LM (2001). Vascular Effects of Progesterone:
Role of Cellular Calcium Regulation. Hypertens Dallas Tex 1979 37(1): 142-147.

57. He Y, Gao Q, Han B, Zhu X, Zhu D, Tao J, Chen J, and Xu Z (2016). Progesterone suppressed vasoconstriction in human umbilical vein via reducing calcium entry. Steroids 108: 118-125.

58. Wu Z and Shen W (2010). Progesterone inhibits L-type calcium currents in gallbladder smooth muscle cells. J Gastroenterol Hepatol 25(12): 1838-1843.

59. Luoma JI, Kelley BG, and Mermelstein PG (2011). Progesterone inhibition of voltage-gated calcium channels is a potential neuroprotective mechanism against excitotoxicity. Steroids 76(9): 845-855.

60. Luoma JI, Stern CM, and Mermelstein PG (2012). Progesterone inhibition of neuronal calcium signaling underlies aspects of progesterone-mediated neuroprotection. J Steroid Biochem Mol Biol 131(12): $30-36$.

61. Cai W, Zhu Y, Furuya K, Li Z, Sokabe M, and Chen L (2008). Two different molecular mechanisms underlying progesterone neuroprotection against ischemic brain damage. Neuropharmacology 55(2): 127-138.

62. Brotfain E, Gruenbaum SE, Boyko M, Kutz R, Zlotnik A, and Klein M (2016). Neuroprotection by Estrogen and Progesterone in Traumatic Brain Injury and Spinal Cord Injury. Curr Neuropharmacol 14(6): 641653.

63. Wei J and Xiao G (2013). The neuroprotective effects of progesterone on traumatic brain injury: current status and future prospects. Acta Pharmacol Sin 34(12): 1485-1490.

64. Pascual JL, Murcy MA, Li S, Gong W, Eisenstadt R, Kumasaka K, Sims C, Smith DH, Browne K, Allen S, and Baren J (2013). Neuroprotective effects of progesterone in traumatic brain injury: blunted in vivo neutrophil activation at the blood-brain barrier. Am J Surg 206(6): 840-845; discussion 845-846.

65. Li Z, Wang B, Kan Z, Zhang B, Yang Z, Chen J, Wang D, Wei H, Zhang $\mathrm{J}$, and Jiang $\mathrm{R}$ (2012). Progesterone increases circulating endothelial progenitor cells and induces neural regeneration after traumatic brain injury in aged rats. J Neurotrauma 29(2): 343-353.

66. Webster KM, Wright DK, Sun M, Semple BD, Ozturk E, Stein DG, O'Brien TJ, and Shultz SR (2015). Progesterone treatment reduces neuroinflammation, oxidative stress and brain damage and improves long-term outcomes in a rat model of repeated mild traumatic brain injury. J Neuroinflammation 12: 238.

67. Gueldener U, Heinisch J, Koehler GJ, Voss D, and Hegemann JH (2002). A second set of loxP marker cassettes for Cre-mediated multiple gene knockouts in budding yeast. Nucleic Acids Res 30(6): e23.

68. Güldener $U$, Heck $S$, Fielder $T$, Beinhauer J, and Hegemann JH (1996). A new efficient gene disruption cassette for repeated use in budding yeast. Nucleic Acids Res 24(13): 2519-2524.

69. Loewith R, Jacinto $E$, Wullschleger S, Lorberg A, Crespo JL, Bonenfant $D$, Oppliger $W$, Jenoe $P$, and Hall MN (2002). Two TOR complexes, only one of which is rapamycin sensitive, have distinct roles in cell growth control. Mol Cell 10(3): 457-468.

70. Kainz K, Tadic J, Zimmermann A, Pendl T, Carmona-Gutierrez D, Ruckenstuhl C, Eisenberg T, and Madeo F (2017). Methods to Assess Autophagy and Chronological Aging in Yeast. Methods in Enzymology.588: 367-394. 